\title{
Cell-Type-Independent Expression of Inwardly Rectifying Potassium Currents in Mouse Fungiform Taste Bud Cells
}

\author{
Yoshiki NAKAO $^{1}$, Masahiro KOSHIMURA ${ }^{2}$, Takashi YAMASAKI ${ }^{2}$, Yoshitaka OHTUBO $^{1}$ \\ ${ }^{1}$ Department of Human Intelligence Systems, Graduate School of Life Science and Systems \\ Engineering, Kyushu Institute of Technology, Kitakyushu, Japan, ${ }^{2}$ Department of Chemical and \\ Biological Engineering, National Institute of Technology (KOSEN), Sasebo College, Sasebo, Japan
}

Received September 27, 2019

Accepted February 25, 2020

Epub Ahead of Print May 29, 2020

\section{Summary}

Inwardly rectifying potassium (Kir) channels play key roles in functions, including maintaining the resting membrane potential and regulating the action potential duration in excitable cells. Using in situ whole-cell recordings, we investigated Kir currents in mouse fungiform taste bud cells (TBCs) and immunologically identified the cell types (type I-III) expressing these currents. We demonstrated that Kir currents occur in a cell-type-independent manner. The activation potentials we measured were -80 to $-90 \mathrm{mV}$, and the magnitude of the currents increased as the membrane potentials decreased, irrespective of the cell types. The maximum current densities at $-120 \mathrm{mV}$ showed no significant differences among cell types ( $p>0.05$, one-way ANOVA). The density of Kir currents was not correlated with the density of either transient inward currents or outwardly rectifying currents, although there was significant correlation between transient inward and outwardly rectifying current densities $(p<0.05$, test for no correlation). RT-PCR studies employing total RNA extracted from peeled lingual epithelia detected mRNAs for Kir1, Kir2, Kir4, Kir6, and Kir7 families. These findings indicate that TBCs express several types of Kir channels functionally, which may contribute to regulation of the resting membrane potential and signal transduction of taste.

\section{Key words}

Potassium • Membrane potentials • Signal transduction

\section{Corresponding author}

Y. Ohtubo, Department of Human Intelligence Systems, Graduate School of Life Science and Systems Engineering, Kyushu Institute of Technology, Hibikino 2-4, Kitakyushu-shi 808-0196, Japan. E-mail: otsubo@brain.kyutech.ac.jp

\section{Introduction}

Taste buds detect taste substances in the oral cavity and transmit the information obtained to taste nerves (Podzimek et al. 2018). A typical taste bud contains 50-150 taste bud cells (TBCs), which are classified into four cell types on the basis of their morphology and functions: type I-IV (Murray 1973, Roper 2013). Type II TBCs express G protein-coupled taste receptors for sweet, bitter, and umami, and they secrete ATP as a transmitter to taste nerves through paracrine signaling (Adler et al. 2000, Chandrashekar et al. 2000, Nelson et al. 2002, Nelson et al. 2001). Type III TBCs are sensitive to acid substances, and they release serotonin through synaptic vesicle-mediated signaling (Huang et al. 2008, Kataoka et al. 2008, Yoshida et al. 2009). Of close relevance to these functional differences among respective TBCs types is the fact that ion channels also express in a cell-type dependent manner: e.g. most outward rectifying currents in type II TBCs are insensitive to tetraethylammonium (TEA) and $\mathrm{Cs}^{+}$ions, which are voltage-gated $\mathrm{K}^{+}$channel blockers, whereas they are sensitive to TEA and $\mathrm{Cs}^{+}$ions in type III TBCs (Kimura et al. 2014, Ohtubo et al. 2012). The channels insensitive to TEA and $\mathrm{Cs}^{+}$ions are considered to be ATP-permeable channels. Recent studies have indicated that calcium homeostasis modulator 1 (CALHM1) and CALHM1/CALHM3 complex channels contribute to ATP secretion from type II TBCs (Kashio et al. 2019, Ma et al. 2017, Ma et al. 2018, Romanov et al. 2018). In addition, type III TBCs functionally and selectively 
express voltage-gated $\mathrm{Ca}^{2+}$ channels for intracellular $\mathrm{Ca}^{2+}$-dependent exocytosis (Clapp et al. 2006, DeFazio et al. 2006). Therefore, it is likely that clarifying the relationship between the cell type and the expression of ion channels will help elucidate the signal transduction mechanisms of taste.

Inwardly rectifying potassium (Kir) channels, through which more current is allowed to flow inward than outward, are expressed in a wide variety of tissue, including rodent TBCs (Kimura et al. 2014, Sun and Herness 1996). Kir channels are known to have diverse physiological functions depending on their type and their location. In TBCs, the Kir2.1 subtype functions as the acid-sensitive $\mathrm{K}^{+}$channel to mediate sour taste transduction (Ye et al. 2016). Moreover, TBCs express ATP-gated $\mathrm{K}^{+}\left(\mathrm{K}_{\text {ATP }}\right)$ channels that are co-expressed with glucose sensors on type 1 taste receptors 3 (T1r3)-positive taste cells to function as the T1r-independent sweet taste of sugar (Yee et al. 2011). However, little is known about the electrophysiological properties of Kir channels in each cell type.

In the present study, we showed that the membrane potential generating the Kir currents in our study was -80 to $-90 \mathrm{mV}$, irrespective of cell types in the physiological conditions, that the current densities of Kir channels did not differ significantly between cell types, and that several types of Kir channel genes were expressed on the peeled lingual epithelia containing fungiform taste buds. We discuss the function of Kir channels in TBCs.

\section{Methods}

All experimental protocols were conducted in compliance with the Guiding Principles for the Care and Use of Animals in the Field of Physiological Sciences approved by the Council of the Physiological Society of Japan, and they were permitted by the Animal Institutional Review Board of Kyushu Institute of Technology, in accordance with the guidelines of the U.S. National Institutes of Health.

\section{Preparation of peeled lingual epithelium}

We peeled the lingual epithelium as described previously (Furue and Yoshii 1997, Furue and Yoshii 1998, Ohtubo et al. 2001). Forty ddY-strain male mice that were used for a general multipurpose model in Japan were purchased from Japan SLC (Hamamatsu, Japan). In brief, we sacrificed, by decapitation, 5-6-week-old
ddY-strain mice anesthetized with $\mathrm{CO}_{2}$, removed the tongue, hypodermically injected a collagenase solution into the tongue, and incubated the tongue at $25^{\circ} \mathrm{C}$ for 3-4 min. We then used forceps under a stereomicroscope to peel off the epithelium containing fungiform papillae. Then, the peeled epithelia were mounted on a recording platform, with the basolateral membrane side of TBCs facing upward. The use of this preparation on the recording platform, allowed us to stably perform patch clamp recordings or optical recordings from TBCs over 1-2 h, as reported previously (Furue and Yoshii 1997, Furue and Yoshii 1998, Hayato et al. 2007, Ohtubo et al. 2001).

In situ whole-cell recordings

We used 24 mice to record voltage-gated currents using a conventional patch clamp method (Bebarova et al. 2015, Wen et al. 2017). Voltage-gated currents of fungiform TBCs were assessed under in situ whole-cell voltage-clamp conditions, as described previously (Furue and Yoshii 1997, Higure et al. 2003). In brief, the peeled epithelia containing TBCs that were mounted on the recording platform were placed under a microscope (BX50; Olympus corporation, Tokyo, Japan) with a $60 \times$ water-immersion objective. Recording electrodes were attached to the basolateral membranes of single TBCs. Under the voltage-clamp condition, voltagegated currents were amplified and filtered at $10 \mathrm{kHz}$ using a voltage-clamp amplifier (Axopatch 200B; Axon Instruments, CA, USA). Data were digitized using an A/D converter (Digidata 1322A; Axon Instruments) and were then stored using pCLAMP data acquisition and analysis software (ver. 9.0; Axon Instruments) on a personal computer. The recording electrode was filled with an intracellular $\mathrm{KCl}$ solution containing $2 \mathrm{mg} / \mathrm{ml}$ biocytin (Sigma-Aldrich, MO, USA) to identify cell types following immunohistostaining. The pipette resistance was approximately $5 \mathrm{M} \Omega$ in physiological saline.

Voltage-gated currents were generated with 40 -ms test potentials of -120 to $+80 \mathrm{mV}$ in 5 - $\mathrm{mV}$ steps every $1 \mathrm{~s}$ from a holding potential of $-70 \mathrm{mV}$ as a test pulse, unless noted otherwise. We attained a mean current of $38-40 \mathrm{~ms}$ at $-120 \mathrm{mV}$ by subtracting leak currents. The magnitude of the leak current at $-120 \mathrm{mV}$ was estimated by extrapolating the current-voltage relationships obtained between -70 and $-50 \mathrm{mV}$. The membrane capacitance of TBCs was measured using pCLAMP data acquisition and analysis software. The magnitude of the maximal and mean currents (pA) through the ion 
channels were divided by the membrane capacitance $(\mathrm{pF})$ of their respective TBCs to obtain the current density $(\mathrm{pA} / \mathrm{pF})$. Further, we compared the current density thus obtained among the respective cell types.

\section{Identification of cell types immunohistochemically}

Following the patch clamp experiments, we stained the peeled epithelium with cell-type-specific antibodies to identify cell types of electrophysiologically recorded TBCs, as described previously (Kimura et al. 2014, Ohtubo et al. 2012). In brief, the peeled epithelia containing the biocytin-injected TBCs were fixed with $4 \%$ paraformaldehyde in phosphate-buffered saline (PBS), and they were then pre-treated with blocking solution containing $3 \%$ normal donkey serum, $0.3 \%$ Triton X, and $1 \%$ bovine serum albumin in PBS for $4 \mathrm{~h}$ at $25^{\circ} \mathrm{C}$. Lastly, immunostaining was carried out using primary antibodies dissolved in blocking solution for 24-48 h at $4{ }^{\circ} \mathrm{C}$. After washing with PBS, the epithelia were incubated with Alexa Fluor-conjugated secondary antibodies and Alexa Fluor 633-conjugated streptavidin (1:100, S21375; Molecular Probe, CA, USA) for 24-48 h at $4{ }^{\circ} \mathrm{C}$.

In this immunohistochemical experiment, we selected the cell-type markers $\mathrm{IP}_{3} \mathrm{R} 3$ for type II cells and selected synaptosomal-associated protein 25 (SNAP-25) for type III cells in accordance with previous reports (Clapp et al. 2001, Ohtubo and Yoshii 2011, Yang et al. 2000). Anti-IP ${ }_{3} \mathrm{R} 3$ mouse monoclonal antibody (1:50, BD-610312; BD Transduction Laboratories, KY, USA), and anti-SNAP-25 rabbit polyclonal antibody (1:1000, S9684; Sigma-Aldrich, MO, USA) were purchased from respective suppliers and used as primary antibodies. Alexa Fluor 488-conjugated donkey anti-rabbit IgG (1:400, A21206; Molecular Probe, OR, USA) and Alexa Fluor 555-conjugated donkey anti-mouse IgG (1:400, A31570; Molecular Probe, OR, USA) were used as secondary antibodies for primary antibodies of corresponding origin.

Immunostained epithelial preparations were viewed under a confocal microscope (TCS-SL; Leica Microsystems, Mannheim, Germany) as described previously (Ohtubo and Yoshii 2011). Confocal images were averaged from two or three images for each focal plane and were obtained over the entire length of the taste buds, with sequential acquisition in $1.5-\mu \mathrm{m}$ steps and at optimal wavelengths for respective fluorescent dyes. Analysis of the averaged confocal images was performed using LAS AF Lite software (ver. 2.6.3; Leica
Microsystems) and Scion Image software (ver. $\beta 4.03$; Scion Corporation, Frederick, MA, USA).

The soma of biocytin-injected TBCs were observed as fluorescent oval shapes and those of cell type markers as immunoreactive rings (Fig. 1D). In the overlay image, when either of the cell type markers surrounded the soma of a biocytin-injected TBC, we identified the TBC as either type II or III. When a biocytin-injected TBC was non-immunoreactive to both markers and contained apical portions, we identified the TBC as a type I cell.

\section{Reverse transcription polymerase chain reaction (RT-PCR)}

To screen for Kir channel gene expression, we performed reverse transcription polymerase chain reaction (RT-PCR) experiments, similar to our previous studies (Eguchi et al. 2008, Hayato et al. 2007, Mori et al. 2016). In brief, we immediately homogenized peeled lingual epithelia containing fungiform taste buds in ISOGEN (317-02503; NIPPON GENE, Tokyo, Japan) and extracted total RNA from the epithelia in ISOGEN according to the manufacturer's protocol. The extracted total RNA was incubated with DNase I solution (2270A; Takara Bio Inc., Siga, Japan) to remove any contaminating-genomic DNA. The cDNA synthesis and PCR were performed using QIAGEN One-Step RT-PCR kits (210212; QIAGEN, Hilden, Germany), unless noted otherwise. Total RNA ( $1 \mu \mathrm{l})$ was added to each premixed RT-PCR solution containing its own primer sets (Table 1). Reverse transcription was performed at $55^{\circ} \mathrm{C}$ for $30 \mathrm{~min}$. PCR cycles consisted of an initial step of $95{ }^{\circ} \mathrm{C}$ for $15 \mathrm{~min}$ and 40 subsequent cycles of $94{ }^{\circ} \mathrm{C}$ for $30 \mathrm{~s}$ (denaturation), $58^{\circ} \mathrm{C}$ for $60 \mathrm{~s}$ (annealing), $72{ }^{\circ} \mathrm{C}$ for $90 \mathrm{~s}$ (extension), and a final extension step of $72^{\circ} \mathrm{C}$ for 10 min with a thermal cycler (GeneAtlas; ASTEC Co., Ltd, Fukuoka, Japan). Amplicons were analyzed using $2 \%$ of agarose gel electrophoresis, stained with ethidium bromide, and visualized using UV illumination.

Specific primers for genes of TBC markers and Kir channels, apart from Kir6.2 (KCNJ11), were designed to span at least one intron by using Primr3Plus (web interface for primer design; http://www.bioinformatics.nl/primer3plus), as shown in Table 1. Using total RNAs extracted from brain, heart, and skeletal muscle, we confirmed that the designed primer sets, apart from Kir3.1 and Kir4.2, yielded a clear single band of the correct size. The primer set for Kir3.1 and Kir4.2 was designed to detect two isoforms. For the 
Kir6.2 (KCNJ11) gene, which has a single exon, in each experiment, we conducted PCR without the RT reaction in parallel with RT-PCR to confirm contamination of genomic DNA. The experimental conditions for this PCR reaction were as follows: total RNA $(1 \mu \mathrm{l})$ was added to premixed PCR solution (KOD-plus-; KOD-201, TOYOBO CO., LTD, Japan), and PCR cycles consisted of an initial step at $94{ }^{\circ} \mathrm{C}$ for $2 \mathrm{~min}, 40$ subsequent cycles at $94{ }^{\circ} \mathrm{C}$ for $30 \mathrm{~s}, 58^{\circ} \mathrm{C}$ for $60 \mathrm{~s}, 68^{\circ} \mathrm{C}$ for $60 \mathrm{~s}$, and a final extension step at $68^{\circ} \mathrm{C}$ for $10 \mathrm{~min}$. We then confirmed that amplicons using primer sets for Kir6.2 yielded no clear single band without RT reaction. The housekeeping gene $\beta$-actin was used for positive control of peeled epithelium, brain, heart, and skeletal muscle. PLC $\beta 2$ and SNAP-25 were used for TBC markers as a positive control.

Table 1. Sequences of primer sets used for RT-PCR.

\begin{tabular}{|c|c|c|c|}
\hline Gene (MGI symbol) & Forward primer $5^{\prime}$ - $3^{\prime}$ & Reverse primer 5' - 3' & $\begin{array}{c}\text { Product size } \\
\text { (bp) }\end{array}$ \\
\hline Kirl.1 (KCNJ1) & CCTCAAAGAAGTCGGCCTTT & CCCTGATCAGCACTCTGCAC & 110 \\
\hline Kir2.1 (KCNJ2) & CTTGCTTCGGCTCATTCTCT & AAGATGTCTGCCAGGTACCT & 554 \\
\hline Kir3.1 (KCNJ3) & AAAAGCTGGAGCAAAAGCCG & GGGCCACCTCTTACCTTTCC & $519(789)$ \\
\hline Kir2.3 (KCNJ4) & GACCCTCCTCGGACCTTAC & AAGATGTCTGCCATGTAGCG & 209 \\
\hline Kir3.4 (KCNJ5) & CTTATCAAGTCCCGGCAGAC & CTGGGAAGGTACTGGAGGAG & 434 \\
\hline Kir3.2 (KCNJ6) & TTCCССТCAACCAGACTGAT & AGCTGAGCCTATAAGGAGGG & 570 \\
\hline Kir6.1 (KCNJ8) & TGGCCACTAGCACCTCTATC & CCTGACATTGGTCACACAGA & 719 \\
\hline Kir3.3 (KCNJ9) & TTTCTCGTCTCACCTCTCGT & CTTTAGCTGTTCCTCGGGAC & 578 \\
\hline Kir4.1 (KCNJ10) & CCCGGACAAACCCTTATCTG & CACACCACACCAAAGAGGAA & 411 \\
\hline Kir6.2 (KCNJ11) & ATAAGGCAGGCTTGTGTGAG & TGCCTGAAGTGCATCTTGTA & 258 \\
\hline Kir2.2 (KCNJ12) & TCCTTGTCTAGTTCAGGCCA & ATGTTGCACTGACCGTTCTT & 521 \\
\hline Kir7.1 (KCNJ13) & TCACAGCTGCATTCTCCTTC & AGAGTACAGCAGAGACACGA & 309 \\
\hline Kir2.4 (KCNJ14) & GACCTGTTCACCACATGTGT & CGATCAGTGCCTCCATCAAA & 569 \\
\hline Kir4.2 (KCNJ15) & ATAGCAGAGCCCCATGGTAG & CACTCCTCTGTGATGGAACG & $510(522)$ \\
\hline Kir5.1 (KCNJ16) & TAACCCTTGCAAGCTGAGAG & CATATGGCGCCACTTGGTAT & 382 \\
\hline$\beta$-actin (Actb) & GTAAAGACCTCTATGCCAACAC & GTGTAAAACGCAGCTCAGTAAC & 289 \\
\hline$P L C \beta 2$ (Plcb2) & CTCGCTTTGGGAAGTTTGC & GCATTGACTGTCATCGGGT & 226 \\
\hline SNAP25 (Snap25) & GGCAATAATCAGGATGGAGTAG & AAATTTAACCACTTCCCAGCA & 310 \\
\hline
\end{tabular}

\section{Solutions}

All solutions were prepared with deionized water and analytical grade reagents, which were purchased from Wako Pure Chemical Industries (Osaka, Japan), unless noted otherwise. The physiological saline solution contained $150 \mathrm{mM} \mathrm{NaCl}, 5 \mathrm{mM} \mathrm{KCl}, 2 \mathrm{mM}$ $\mathrm{CaCl}_{2}, \quad 0.5 \mathrm{mM} \mathrm{MgCl}_{2}, 10 \mathrm{mM}$ glucose, and $5 \mathrm{mM}$ HEPES-NaOH (pH 7.4; Sigma-Aldrich, MO, USA). The intracellular $\mathrm{KCl}$ solution contained $120 \mathrm{mM} \mathrm{KCl}$, $2.4 \mathrm{mM} \mathrm{CaCl}_{2}, 5 \mathrm{mM} \mathrm{MgCl}_{2}, 10 \mathrm{mM}$ EGTA (Dojindo Laboratories, Kumamoto, Japan), $30 \mathrm{mM} \mathrm{KOH,} 5 \mathrm{mM}$ $\mathrm{Na}_{2} \mathrm{ATP}, \quad 0.3 \mathrm{mM} \quad \mathrm{Na}_{3} \mathrm{GTP}, \quad 10 \mathrm{mM}$ HEPES-KOH (pH 7.2; Sigma-Aldrich, MO, USA), and $2 \mathrm{mg} / \mathrm{ml}$ biocytin (Sigma-Aldrich, MO, USA). The collagenase solution consisted of $4 \mathrm{mg} / \mathrm{ml}$ collagenase type I dissolved in physiological saline. PBS contained $137 \mathrm{mM}$ $\mathrm{NaCl}, 8.1 \mathrm{mM} \mathrm{Na} \mathrm{HPO}_{4}, 2.68 \mathrm{mM} \mathrm{KCl}$, and $1.47 \mathrm{mM}$ $\mathrm{KH}_{2} \mathrm{PO}_{4}$.

Statistics

Data of current densities obtained from the respective cell types (I-III) were analyzed using one-way ANOVA following Scheffe's multiple comparison test. Bartlett's test was used to determine whether the population showed equal variances among samples. A test for no correlation was used to determine the correlation between the current densities. The data are shown as means \pm standard deviations (SDs), unless noted otherwise. 


\section{Results}

\section{Identification of cell types}

To avoid misidentification, we injected biocytin into only one TBC in each lingual epithelium during the electrophysiological examinations. The injected biocytin diffused into the whole subcellular space of TBCs, including apical portions and the nuclei (Fig. 1). In contrast, the immunoreactive regions for $\mathrm{IP}_{3} \mathrm{R} 3$ and SNAP25 were observed as a ring surrounding the nucleus of TBCs. These confocal images were similar to those obtained in previous reports (Kimura et al. 2014, Ohtubo et al. 2012). When either of the cell type markers surrounded the cell body of a biocytin-injected TBC, we identified the TBC as either type II or type III (Fig. 1). When a biocytininjected TBC was non-immunoreactive to both markers and contained apical portions, we identified the TBC as a type I cell because type IV cells are oval and do not contain apical portions. We successfully injected biocytin into $24 \mathrm{TBCs}$, resulting in the identification of four type I, seven type II, and five type III cells following the electrophysiological recordings. The cell types of the eight remaining TBCs could not be identified because they were lost during the immunohistostaining processes.

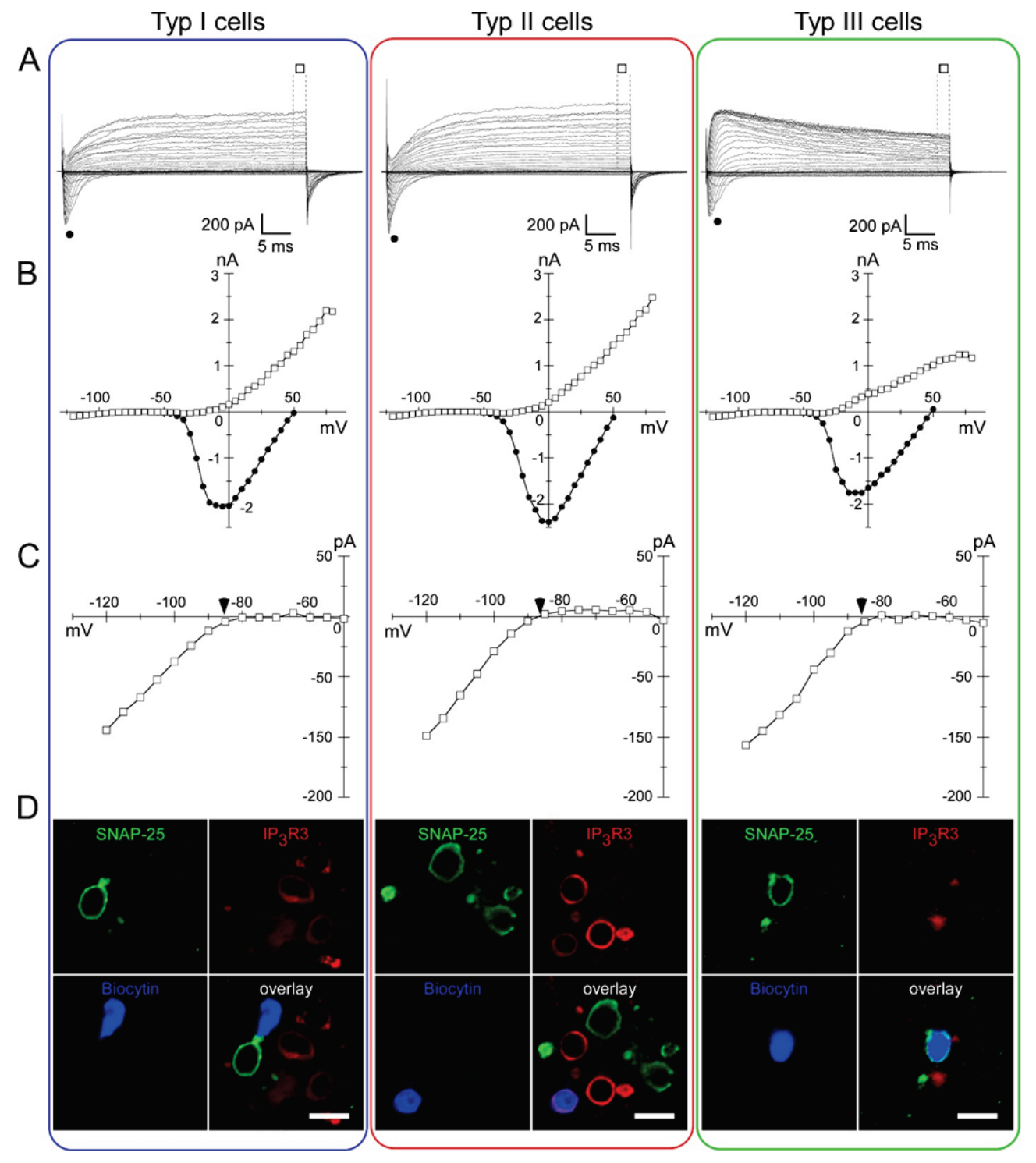

Fig. 1. Representative traces of voltage-gated currents obtained from a type I cell (non-immunoreactive cell, non-IRC), a type II cell (IP ${ }_{3}$ R3-IRC), and a type III cell (SNAP-25-IRC). Row (A): A family of voltage-gated currents obtained from the TBC. The currents are generated by test potentials from -120 to $+80 \mathrm{mV}$ in $5-\mathrm{mV}$ increments from the holding potential of $-70 \mathrm{mV}$. Row (B): Current-voltage (I-V) curves of respective TBCs, as shown in Row A. Symbols: peak transient inward current magnitude (closed circles) and averaged outwardly rectifying current magnitude (open squares), as shown in Row A. Row (C): Magnified I-V curves indicating the inwardly rectifying $\mathrm{K}^{+}$currents. Arrow heads indicate the equilibrium potentials of $\mathrm{K}^{+}$ions under our experimental conditions. Row (D): Immunoreactivity of cell type markers (green; SNAP-25, red; $\mathrm{IP}_{3} \mathrm{R} 3$ ) and biocytin-injected TBCs (blue), from which these currents were recorded. Scale bars, $10 \mu \mathrm{m}$. 
Inward rectifying $\mathrm{K}^{+}$currents

TBCs of each cell type generated inward rectifying $\mathrm{K}^{+}$(Kir) currents, in addition to outwardly rectifying currents and transient inward currents (Fig. 1). The membrane potential generating the Kir currents was at -80 to $-90 \mathrm{mV}$, irrespective of cell type, and the magnitudes of the currents increased almost linearly with decreasing membrane potentials. The mean membrane capacitances of respective cell types were $6.0 \pm 0.3 \mathrm{pF}$ (mean \pm S.D, $n=4)$ in type I cells, $5.8 \pm 1.0 \mathrm{pF}(\mathrm{n}=7)$ in type II cells, $5.9 \pm 1.1 \mathrm{pF}(\mathrm{n}=5)$ in type III cells, which is consistent with previous studies on the membrane capacitance of TBCs (Iwamoto et al. 2020, Kimura et al. 2014). There were no significant differences among the membrane capacitances of each cell type $(p>0.05$, oneway ANOVA). The mean current densities, i.e. the mean currents in magnitude divided by membrane capacitance, of Kir currents were $-20.9 \pm 13.0 \mathrm{pA} / \mathrm{pF}$ (mean \pm S.D, $\mathrm{n}=4$ ) in type I cells, $-20.8 \pm 15.6 \mathrm{pA} / \mathrm{pF}(\mathrm{n}=7)$ in type II cells, and $-19.3 \pm 6.0 \mathrm{pA} / \mathrm{pF}(\mathrm{n}=5)$ in type III cells at $-120 \mathrm{mV}$ (Fig. 2). Although variance in type I and type II cells tended to be larger than that in type III cells, there was homogeneity of variance ( $p>0.05$, Bartlett's test). There was no significant difference among cell types $(p>0.05$, one-way ANOVA). These finding indicate that TBCs functionally express Kir channels with similar current density among cell types, although the current density appears to differ between individual cells.

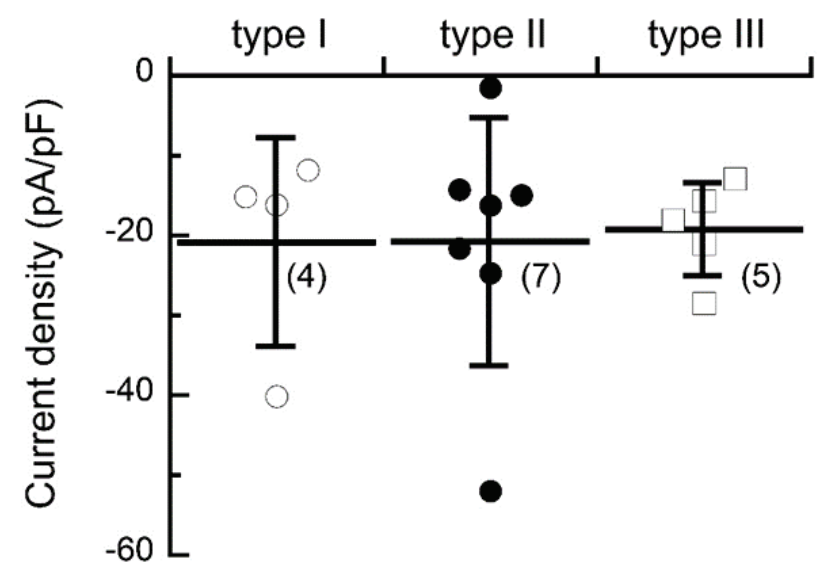

Fig. 2. Comparison of inwardly rectifying potassium current densities between cell types. Plotted data are current densities, i.e. current magnitude at $-120 \mathrm{mV}$ divided by the membrane capacitance of respective cells. Horizontal and vertical bars indicate means and SDs, respectively. There were no significant differences in the current densities between cell types $(p>0.05$, one-way ANOVA). Numerals in parentheses indicate the number of TBCs examined.
To examine the relationship between the functional expression of Kir channels and of other voltage-gated channels, we compared the correlation of the current densities of ion channels (Fig. 3). There were no correlations either between the density of Kir currents and that of transient inward currents, or between the density of Kir currents and that of outwardly rectifying currents. Conversely, there was significant correlation between the density of transient inward currents and that of outwardly rectifying currents $(p<0.05$, test for no correlation). According to previous pharmacological studies, the voltage-gated transient inward currents likely arise from the activation of voltage-gated $\mathrm{Na}^{+}$channels (Furue and Yoshii 1997, Higure et al. 2003, Noguchi et al. 2003). Therefore, significant correlation between voltage-gated $\mathrm{Na}^{+}$and outwardly rectifying currents facilitates the formation of action potentials.

\section{$R T-P C R$}

A total of 15 Kir subunit genes have been identified and classified into seven (Kir 1-7) subfamilies (Hibino et al. 2010, Reimann and Ashcroft 1999). To study the gene expression of these Kir subunits, we performed RT-PCR experiments using total RNA extracted from mouse peeled lingual epithelia containing fungiform taste buds. The results of RT-PCR revealed the expression of KCNJ1, KCNJ4, KCNJ10, KCNJ11, KCNJ12, KCNJ13, KCNJ14, and KCNJ15 (Fig. 4). Although $\mathrm{KCNJ} 2$ and $\mathrm{KCNJ} 3$ genes in the control experiments were detected by clear bands of the correct molecular size, those in the peeled lingual epithelia showed multiple bands. Thus, the expression of these two genes is unclear. The same results were obtained four times in independent experiments.

\section{Discussion}

In this study, the main finding is that all type I-III cells generate inwardly rectifying $\mathrm{K}^{+}$(Kir) currents activated at -80 to $-90 \mathrm{mV}$ in our experimental condition. In addition, we have shown that the densities of the currents flowing Kir channels do not differ significantly between cell types. Therefore, it is likely that the functional significance of Kir channels may be in serving common roles, e.g. maintenance of the resting potentials, in addition to cell-type-specific roles, as contributions to sour and sugar taste transduction. To function in these various roles, TBCs express multiple types of genes for Kir channels, as indicated in both this study and previous studies (Ye et al. 2016, Yee et al. 2011). 
A

Inwardly rectifying potassium current density

B

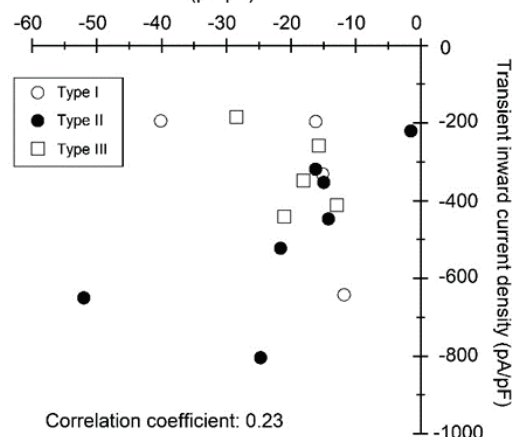

C

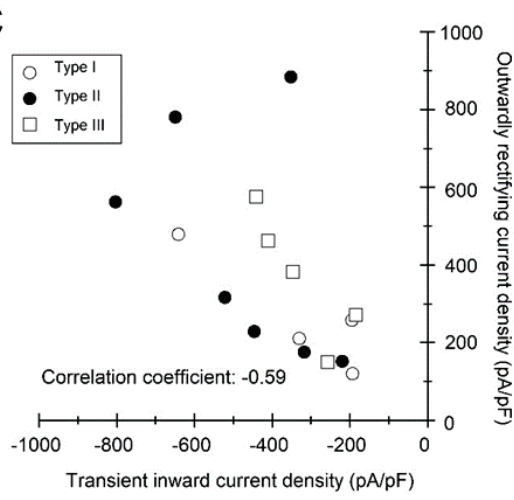

Fig. 3. Correlation between densities of inwardly rectifying potassium currents and other voltage-gated currents. There were no correlations either between the density of inwardly rectifying potassium currents and transient inward currents (A), or between the density of inwardly rectifying potassium currents and outwardly rectifying currents (B). Conversely, there was significant correlation between the density of transient inward currents and outwardly rectifying currents (C); $p<0.05$, test for no correlation).
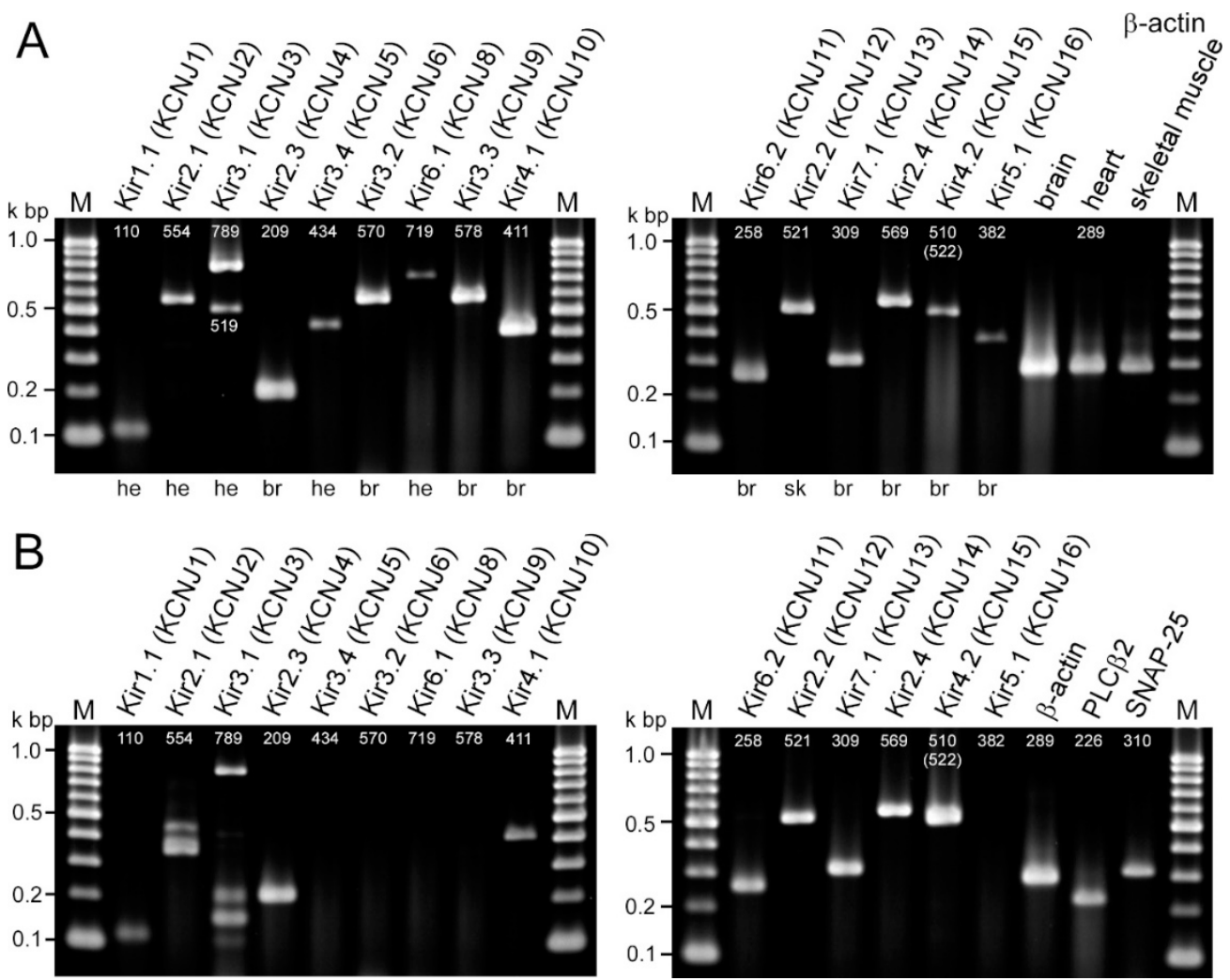

Fig. 4. Expression of Kir1, Kir2, Kir4, Kir6, and Kir7 mRNAs in peeled lingual epithelia. (A) Control studies with the primer sets used. Total RNAs were extracted from organs, such as mouse brains (br), hearts (he), and skeletal muscles (sk), in which the expression of respective Kir mRNAs was reported. Numerals in each line indicate expected product sizes. Examined primer sets, except for Kir3.1 and Kir4.2, yielded a clear single band with a correct size. The primer set for Kir3.1 and Kir4.2 was designed to detect two isoforms. (B) RT-PCR studies using total RNA extracted from peeled lingual epithelia containing fungiform taste buds detected the mRNAs of Kir1.1, Kir2.3, Kir4.1, Kir6.2, Kir2.2, Kir7.1, Kir2.4, and Kir4.2. Identical results were obtained in other RT-PCR experiments. Positive controls: $\beta$-actin, PLCB2, and SNAP-25. M denotes molecular size markers. 
In all cell types, the Kir current was generated at -80 to $-90 \mathrm{mV}$, and it increased almost linearly with decreasing membrane potentials. The equilibrium potential (EK) of $\mathrm{K}^{+}$ions was approximately $-86 \mathrm{mV}$ under our experimental conditions. As Kir channels are known to generate a large $\mathrm{K}^{+}$conductance at membrane potentials negative to $\mathrm{EK}$, our findings obtained from TBCs are consistent with this feature of Kir channels expressed in other tissues (Hibino et al. 2010).

The correlation coefficient between the density of Kir currents and transient inward currents was 0.23 , and that between that of Kir currents and outwardly rectifying currents, which are non-correlated $(p>0.05$, test for no correlation), was -0.29 . However, there was significant correlation between the density of transient inward currents and outwardly rectifying currents $(-0.59$; $p<0.05$, test for no correlation). Irrespective of cell types, the transient inward currents are voltage-gated $\mathrm{Na}^{+}$currents based on electrophysiological and pharmacological relevant properties, as reported previously (Higure et al. 2003, Kimura et al. 2014, Ohtubo et al. 2012). Conversely, most of the outwardly rectifying currents in type III cells are voltage-gated $\mathrm{K}^{+}$currents and those in type II cells are $\mathrm{Cs}^{+}$-insensitive currents, likely ATP-permeable currents (Kimura et al. 2014, Romanov et al. 2007). As both voltage-gated $\mathrm{K}^{+}$ and ATP-permeable currents contribute to the falling phase of action potentials, it stands to reason that there is significant correlation between the density of transient inward currents and that of outwardly rectifying currents.

Although the resting membrane potential of individual TBCs is unclear, the differences in the resting membrane potentials of individual type II cells may affect the taste signal transduction. Type II cells that detect umami, bitter, and sweet substances secrete ATP to taste nerve endings as a predominant transmitter via membrane depolarization with action potentials. Because the equilibrium between closed and inactivated states of voltage-gated $\mathrm{Na}^{+}$channels depends on the membrane potentials, the membrane potential just before receiving the taste substances may affect the ATP secretion. If a TBC has shallower resting membrane potentials, the number of inactivated $\mathrm{Na}^{+}$channels increases. Hence, the action potential dependent-ATP secretion in this TBC may be decreased. In this study, we detected mRNAs for Kir6.2, although the Kir6.2-expressing cell types were unclear. Kir6.2 is a subunit of ATP-sensitive $\mathrm{K}^{+}$channels (Hibino et al. 2010, Nichols 2006). It is possible that if some type II cells express Kir6.2 channels, individual type II cells may have different resting membrane potentials, as the intracellular concentration of ATP and ADP controls channel activity. These electrophysiological differences in individual type II cells might be important for taste signal transduction. Further experiments using a combination of patch clamp recording and single-cell RT-PCR are necessary to clarify the relationships between the resting membrane potentials of type II cells, the expression of Kir6.2 channels, and the signal transduction of taste.

\section{Conflict of Interest}

There is no conflict of interest.

\section{Acknowledgements}

This research was partially supported by Mr. Motoaki Miyoshi, the president of Miyoshi Rice Store, and by JSPS KAKENHI Grant-in-Aid for Scientific Research (C), Grant Number 15K07053.

\section{References}

ADLER E, HOON MA, MUELLER KL, CHANDRASHEKAR J, RYBA NJ, ZUKER CS: A novel family of mammalian taste receptors. Cell 100: 693-702, 2000. https://doi.org/10.1016/s0092-8674(00)80705-9

BEBAROVA M, MATEJOVIC P, SIMURDOVA M, SIMURDA J: Acetaldehyde at clinically relevant concentrations inhibits inward rectifier potassium current I(K1) in rat ventricular myocytes. Physiol Res 64: 939-943, 2015. https://doi.org/10.1007/s00210-017-1341-z

CHANDRASHEKAR J, MUELLER KL, HOON MA, ADLER E, FENG L, GUO W, ZUKER CS, RYBA NJ: T2Rs function as bitter taste receptors. Cell 100: 703-711, 2000. https://doi.org/10.1016/s0092-8674(00)80706-0

CLAPP TR, MEDLER KF, DAMAK S, MARGOLSKEE RF, KINNAMON SC: Mouse taste cells with G proteincoupled taste receptors lack voltage-gated calcium channels and SNAP-25. BMC Biol 4: 7, 2006. https://doi.org/10.1186/1741-7007-4-7

CLAPP TR, STONE LM, MARGOLSKEE RF, KINNAMON SC: Immunocytochemical evidence for co-expression of Type III IP3 receptor with signaling components of bitter taste transduction. BMC Neurosci 2: 6, 2001. https://doi.org/10.1186/1471-2202-2-6 
DEFAZIO RA, DVORYANCHIKOV G, MARUYAMA Y, KIM JW, PEREIRA E, ROPER SD, CHAUDHARI N: Separate populations of receptor cells and presynaptic cells in mouse taste buds. J Neurosci 26: 3971-3980, 2006. https://doi.org/10.1523/jneurosci.0515-06.2006

EGUCHI K, OHTUBO Y, YOSHII K: Functional expression of M3, a muscarinic acetylcholine receptor subtype, in taste bud cells of mouse fungiform papillae. Chem Senses 33: 47-55, 2008. https://doi.org/10.1093/chemse/bjm065

FURUE H, YOSHII K: In situ tight-seal recordings of taste substance-elicited action currents and voltage-gated Ba currents from single taste bud cells in the peeled epithelium of mouse tongue. Brain Res 776: 133-139, 1997. https://doi.org/10.1016/s0006-8993(97)00974-8

FURUE H, YOSHII K: A method for in-situ tight-seal recordings from single taste bud cells of mice. J Neurosci Methods 84: 109-114, 1998. https://doi.org/10.1016/s0165-0270(98)00104-6

HAYATO R, OHTUBO Y, YOSHII K: Functional expression of ionotropic purinergic receptors on mouse taste bud cells. J Physiol 584: 473-488, 2007. https://doi.org/10.1113/jphysiol.2007.138370

HIBINO H, INANOBE A, FURUTANI K, MURAKAMI S, FINDLAY I, KURACHI Y: Inwardly rectifying potassium channels: their structure, function, and physiological roles. Physiol Rev 90: 291-366, 2010. https://doi.org/10.1152/physrev.00021.2009

HIGURE Y, KATAYAMA Y, TAKEUCHI K, OHTUBO Y, YOSHII K: Lucifer Yellow slows voltage-gated $\mathrm{Na}+$ current inactivation in a light-dependent manner in mice. J Physiol 550: 159-167, 2003. https://doi.org/10.1113/jphysiol.2003.040733

HUANG YA, MARUYAMA Y, STIMAC R, ROPER SD: Presynaptic (Type III) cells in mouse taste buds sense sour (acid) taste. J Physiol 586: 2903-2912, 2008. https://doi.org/10.1113/jphysiol.2008.151233

IWAMOTO M, TAKASHIMA M, OHTUBO Y: A subset of taste receptor cells express biocytin-permeable channels activated by reducing extracellular $\mathrm{Ca}(2+)$ concentration. Eur J Neurosci 51: 1605-1623, 2020. https://doi.org/10.1111/ejn.14672

KASHIO M, WEI-QI G, OHSAKI Y, KIDO MA, TARUNO A: CALHM1/CALHM3 channel is intrinsically sorted to the basolateral membrane of epithelial cells including taste cells. Sci Rep 9: 2681, 2019. https://doi.org/10.1038/s41598-019-39593-5

KATAOKA S, YANG R, ISHIMARU Y, MATSUNAMI H, SÉVIGNY J, KINNAMON JC, FINGER TE: The candidate sour taste receptor, PKD2L1, is expressed by type III taste cells in the mouse. Chem Senses 33: 243-254, 2008. https://doi.org/10.1093/chemse/bjm083

KIMURA K, OHTUBO Y, TATENO K, TAKEUCHI K, KUMAZAWA T, YOSHII K: Cell-type-dependent action potentials and voltage-gated currents in mouse fungiform taste buds. Eur J Neurosci 39: 24-34, 2014. https://doi.org/10.1111/ejn.12388

MA Z, SAUNG WT, FOSKETT JK: Action potentials and ion conductances in wild-type and CALHM1-knockout type II taste cells. J Neurophysiol 117: 1865-1876, 2017. https://doi.org/10.1152/jn.00835.2016

MA Z, TARUNO A, OHMOTO M, JYOTAKI M, LIM JC, MIYAZAKI H, NIISATO N, MARUNAKA Y, LEE RJ, HOFF H, PAYNE R, DEMURO A, PARKER I, MITCHELL CH, HENAO-MEJIA J, TANIS JE, MATSUMOTO I, TORDOFF MG, FOSKETT JK: CALHM3 is essential for rapid ion channel-mediated purinergic neurotransmission of GPCR-mediated tastes. Neuron 98: 547-561.e10, 2018. https://doi.org/10.1016/j.neuron.2018.03.043

MORI Y, EGUCHI K, YOSHII K, OHTUBO Y: Selective expression of muscarinic acetylcholine receptor subtype M3 by mouse type III taste bud cells. Pflugers Arch 468: 2053-2059, 2016. https://doi.org/10.1007/s00424-0161879-5

MURRAY RG: The ultrastructure of taste buds In: The Ultrastructure of Sensory Organs. FRIEDMANN I (ed.), Amsterdam: North-Holland Publishing Company, 1973, pp 1-81.

NELSON G, CHANDRASHEKAR J, HOON MA, FENG L, ZHAO G, RYBA NJP, ZUKER CS: An amino-acid taste receptor. Nature 416: 199-202, 2002. https://doi.org/10.1038/nature726

NELSON G, HOON MA, CHANDRASHEKAR J, ZHANG Y, RYBA NJ, ZUKER CS: Mammalian sweet taste receptors. Cell 106: 381-390, 2001. https://doi.org/10.1016/s0092-8674(01)00451-2 
NICHOLS CG: KATP channels as molecular sensors of cellular metabolism. Nature 440: 470-476, 2006. https://doi.org/10.1038/nature04711

NOGUCHI T, IKEDA Y, MIYAJIMA M, YOSHII K: Voltage-gated channels involved in taste responses and characterizing taste bud cells in mouse soft palates. Brain Res 982: 241-259, 2003. https://doi.org/10.1016/s0006-8993(03)03013-0

OHTUBO Y, IWAMOTO M, YOSHII K: Subtype-dependent postnatal development of taste receptor cells in mouse fungiform taste buds. Eur J Neurosci 35: 1661-1671, 2012. https://doi.org/10.1111/j.1460-9568.2012.08068.X

OHTUBO Y, SUEMITSU T, SHIOBARA S, MATSUMOTO T, KUMAZAWA T, YOSHII KY: Optical recordings of taste responses from fungiform papillae of mouse in situ. J Physiol 530: 287-293, 2001. https://doi.org/10.1111/j.1469-7793.2001.02871.x

OHTUBO Y, YOSHII K: Quantitative analysis of taste bud cell numbers in fungiform and soft palate taste buds of mice. Brain Res 1367: 13-21, 2011. https://doi.org/10.1016/j.brainres.2010.10.060

PODZIMEK S, DUSKOVA M, BROUKAL Z, RACZ B, STARKA L, DUSKOVA J: The evolution of taste and perinatal programming of taste preferences. Physiol Res 67 (Suppl 3): S421-S429, 2018. https://doi.org/10.33549/physiolres.934026

REIMANN F, ASHCROFT FM: Inwardly rectifying potassium channels. Curr Opin Cell Biol 11: 503-508, 1999. https://doi.org/10.1016/s0955-0674(99)80073-8

ROMANOV RA, LASHER RS, HIGH B, SAVIDGE LE, LAWSON A, ROGACHEVSKAJA OA, ZHAO H, ROGACHEVSKY VV, BYSTROVA MF, CHURBANOV GD, ADAMEYKO I, HARKANY T, YANG R, KIDD GJ, MARAMBAUD P, KINNAMON JC, KOLESNIKOV SV, FINGER TE: Chemical synapses without synaptic vesicles: Purinergic neurotransmission through a CALHM1 channel-mitochondrial signaling complex. Sci Signal 11: 529, 2018. https://doi.org/10.1126/scisignal.aao1815

ROMANOV RA, ROGACHEVSKAJA OA, BYSTROVA MF, JIANG P, MARGOLSKEE RF, KOLESNIKOV SS: Afferent neurotransmission mediated by hemichannels in mammalian taste cells. EMBO J 26: 657-667, 2007. https://doi.org/10.1038/sj.emboj.7601526

ROPER SD: Taste buds as peripheral chemosensory processors. Semin Cell Dev Biol 24: 71-79, 2013. https://doi.org/10.1016/j.semcdb.2012.12.002

SUN XD, HERNESS MS: Characterization of inwardly rectifying potassium currents from dissociated rat taste receptor cells. Am J Physiol 271: C1221-C1232, 1996. https://doi.org/10.1152/ajpcell.1996.271.4.c1221

WEN RJ, HUANG D, ZHANG Y, LIU YW: Bis(3)-tacrine inhibits the sustained potassium current in cultured rat hippocampal neurons. Physiol Res 66: 539-544, 2017. https://doi.org/10.33549/physiolres.933354

YANG R, CROWLEY HH, ROCK ME, KINNAMON JC: Taste cells with synapses in rat circumvallate papillae display SNAP-25-like immunoreactivity. J Comp Neurol 424: 205-215, 2000. https://doi.org/10.1002/10969861(20000821)424:2<205::aid-cne2>3.0.co;2-f

YE W, CHANG RB, BUSHMAN JD, TU YH, MULHALL EM, WILSON CE, COOPER AJ, CHICK WS, HILL-EUBANKS DC, NELSON MT, KINNAMON SC, LIMAN ER: The K+ channel KIR2.1 functions in tandem with proton influx to mediate sour taste transduction. Proc Natl Acad Sci U S A 113: E229-E238, 2016. https://doi.org/10.1073/pnas.1514282112

YEE KK, SUKUMARAN SK, KOTHA R, GILBERTSON TA, MARGOLSKEE RF: Glucose transporters and ATP-gated K+ (KATP) metabolic sensors are present in type 1 taste receptor 3 (T1r3)-expressing taste cells. Proc Natl Acad Sci U S A 108: 5431-5436, 2011. https://doi.org/10.1073/pnas.1100495108

YOSHIDA R, MIYAUCHI A, YASUO T, JYOTAKI M, MURATA Y, YASUMATSU K, SHIGEMURA N, YANAGAWA Y, OBATA $\mathrm{K}$, UENO H, MARGOLSKEE RF, NINOMIYA Y: Discrimination of taste qualities among mouse fungiform taste bud cells. J Physiol 587: 4425-4439, 2009. https://doi.org/10.1113/jphysiol.2009.175075 